\title{
Öğrencilerin Fen Bilimleri Derslerindeki Başarılarına Etki Eden Faktörlerin Belirlenmesine Yönelik Bir Ölçeğin Geliştirilmesi
}

\author{
Erdal TATAR \\ Cemal TOSUN* \\ Cengiz TÜYSÜZ \\ Nail ILHAN***** \\ Yunus KARAKUYU*****
}

\section{Öz}

$\mathrm{Bu}$ çalışma, öğrencilerin fen başarılarına etki eden faktörleri tespit etmeye yönelik geçerli ve güvenilir bir ölçeğin geliştirilmesi amaçlanmıştır. Fen Başarısına Etki Eden Faktörler Ölçeği (FBEFÖ) geliştirilirken öncelikle öğrenci görüşlerine başvurularak ve ilgili eğitim literatüründen faydalanılarak madde havuzu oluşturulmuştur. Ölçeğin kapsam geçerliğinin belirlenmesi amacıyla uzman görüşü alınmıştır. Uzman görüşü doğrultusunda revize edilen ölçek 681 üniversite öğrencisine uygulanmıştır. Yapılan madde analizi sonucunda madde toplam korelasyon değeri .30'dan küçük olan maddeler ölçekten çıkarılmıştır. Açımlayıcı faktör analizi yapıldıktan sonra binişik olduğu düşünülen maddeler çıarılmış ve son haliyle ölçeğin toplam varyansın \%45.045'ini açıladığı görülmüştür. Öğrenci, öğretmen, materyal, öğrenme ortamı ve öğretim programı şeklinde beş alt boyuttan oluşan toplam 29 maddelik ölçeğin tamamı için CronbachAlpha iç tutarlık katsayısı .865 olarak hesaplanmıştır. Çalışma sonucunda geçerlik ve güvenirliği ortaya konan geliştirilen ölçeğin, ilerde fen başarısı belirleyicileri üzerinde yapılan araştırmalar için 1şık tutacağ 1 düşünülen geçerli, güvenilir ve kullanışlı bir ölçek olduğu düşünülmektedir.

Anahtar Kelimeler: Fen Başarısı Belirleyicileri, Öğretmen, Öğrenci, Materyal, Öğrenme Ortamı, Öğretim Programı.

${ }^{*}$ Doç. Dr., Mustafa Kemal Üniversitesi, Eğitim Fakültesi, Fen Bilgisi Eğitimi Anabilim Dalı

** Yrd. Doç. Dr., Bartın Üniversitesi, Eğitim Fakültesi, Fen Bilgisi Eğitimi Anabilim Dalı

*** Doç. Dr., Mustafa Kemal Üniversitesi, Eğitim Fakültesi, Fen Bilgisi Eğitimi Anabilim Dalı

${ }^{* * * * *}$ Yrd. Doç. Dr., Kilis 7 Aralık Üniversitesi, M. R. Eğitim Fakültesi, Fen Bilgisi Eğitimi Anabilim Dalı

****** Doç. Dr., Uşak Üniversitesi, Eğitim Fak. İlköğretim Bölümü 


\title{
Developing a Scale to Determining Factors Affecting Students' Achievement in Science
}

\begin{abstract}
This study aimed to develop a valid and reliable scale which would identify factors affecting students' achievement in science. Firstly, it was an item pool for Scale of Factors Affecting the Science Achievement (SFASA) by referring the students' opinions and utilizing related educational literature. Then the expert opinion was taken to determine the content validity of the scale. The revised scale by experts' opinions was applied to 681 university students. Items that was smaller than their correlation value of .30 was removed from the scale after the item analysis. After exploratory factor analysis, comorbid items are removed from the scale. It has been shown that the final version of the scale is explaining $45045 \%$ of total variance. The scale is consisting of 29 items in five subscales of students, teachers, material, learning environment and curriculum. Cronbach's alpha reliability coefficient was calculated to be .865 for full scale. This scale is considered to be a reliable and valid instrument and to shed light on research done about Predictors of science achievement in the future.

Keywords: Predictors of Science Achievement, Teacher, Student, Material, Learning Environment, Curriculum.

\section{Giriş}

Dünyada birçok ülkede, eğitim kalitesinin değerlendirilmesi için öncelikle fen başarıları değerlendirilmektedir. "Uluslararası Öğrenci Değerlendirme Programı" olan PISA ile 15 yaş grubu öğrencilerin başarıları incelenmektedir. Ülkeler, öğrenci başarıları düzeylerine göre, öğretim programlarını yenilemektedirler.

Literatürde fen başarısına etki eden faktörler üzerinde yapılmış birçok araştırma yer almaktadır. Bu araştırmalardan bir kısmı, bağımsız değişkenler olarak öğrencilerin özelliklerini, bir kısmı okul özelliklerini bir kısmı ise diğer çevresel faktörleri esas alan modellemeleri kullanarak bu faktörlerin fen başarısı üzerindeki etkilerini tartışmışlardır. Örneğin; ailenin sosyo ekonomik düzeyi (Lytton \& Pyryt, 1998), cinsiyet (Bursal, 2013), özyeterlik inançları (Lavonen \& Laaksonen, 2009), motivasyon (Osborne, Simon \& Collins, 2003), başarı ve başarısızlık algısı (Berberoğlu vd., 2003), öğretim modelleri (Wu\&Tsai, 2005), tutum (Papanastasiou ve Zembylas, 2004), çevresel faktörler (Thomson \& De Bortoli, 2007), duygusal faktörler
\end{abstract}


(Ozel, Cağlak ve Erdogan, 2013), sınıf büyüklüğü ve mevcudu (Tanner, 2000), öğretmenin cinsiyeti ve deneyim (Liu, Lee \& Linn, 2010) bu değişkenlerden yalnızca birkaçıdır. İnsan sosyal bir varlık olduğundan onu etkileyen her bir faktör onun öğrenmesini ve dolayısıyla da fen öğrenimini etkileyecektir. Bu noktadan hareketle yukarıda sayılan değişkenlerin yüzlercesi üzerinde başarıya odaklanan hipotezler kurulabilir. Fen eğitimi araştırmalarında, başarı bağımlı değişkenine etki eden belirleyicilere dayalı çalışmaların çokluğu da bu görüşü desteklemektedir.

Öğretim ve öğrenme süreçleri karmaşık süreçlerdir ve birçok faktörden doğrudan ve dolaylı olarak etkilenmektedirler (Mohammadpour, 2012). Fen öğrenimine dolayısıyla fen başarısına katkıda bulanan her bir faktör ya da başka bir deyişle belirleyici, fen öğretimi politikalarını, öğretim programlarını ve hatta bunlar üzerinde kurgulanan ileriki araştırmaları etkilediğinden ayrıca önem taşımaktadır. Bununla birlikte fen başarısı belirleyicilerinin hangisinin başarıya daha çok katkıda bulunduğu, hangi coğrafyada ve örneklemde daha çok öne çıktığı ve diğer belirleyicilerle olan ilişkisinin ne olduğu ayrı ayrı çalışılması gereken araştırma sorularıdır. Bu tür soruların çözümüne katkıda bulunacak olan, bütüncül bir bakışla konuyu ele alan ve geniş bir belirleyici yelpazesinde çalışan araştırmaların sayısı ise henüz yeterli miktarda değildir. Diğer taraftan bu tür verilerin toplanmasında kullanılacak, fen başarısı belirleyicilerinin önem derecelerinin nasıl algılandığına ve katkı düzeylerinin ne olduğunu belirlemeye yönelik argüman sayısının da sınırlı olduğu görülmektedir. Bu çalışmada yukarıda belirtilen ihtiyacı karşılamaya yönelik olarak fen başarısına etki eden faktörleri tespit edebilecek bir ölçeğin geliştirilmesi amaçlanmıştır.

\section{Yöntem}

Bu çalışmada, Fen Başarısına Etki Eden Faktörler (FBEF) ölçeğinin geliştirilmesi amaçlanmaktadır. Ölçeğin geçerliğinin ve güvenirliğinin ortaya konulmasında yapılan işlemler ve çalışmada yer verilen örneklem aşağıda açılanmıştır.

\section{Örneklem}

Çalışmanın hedef evrenini Türkiye'de fen bilimleri alanlarında lisans öğrenimi görmüş veya görmekte olan üniversite öğrencileri oluşturmaktadır. Örneklem, tesadüfi olmayan örnekleme yöntemlerinden uygun örnekleme yöntemi kullanılarak belirlenmiştir. Çoğu zaman tesadüfi ya da sistematik olarak örneklem seçmenin zor olduğu durumlarda araştırmacılar uygun örnekleme yöntemini kullanabilirler. Bu yöntemde 
örneklem çalışma için kolayca ulaşılabilen kişilerden oluşur (Fraenkel, Wallen ve Hyun, 2012). Çalışmanın örneklemini 2014-2015 öğretim yılında öğrenim görmekte olan 406 fen bilgisi öğretmenliği programı öğrencisi ve aynı öğretim yılında fizik, kimya ve biyoloji alanında formasyon eğitimi almakta olan 275 öğretmen adayı olmak üzere toplam 681 üniversite öğrencisi oluşturmuştur. Örneklem, Bartın, Hatay, Kilis ve Uşak illerindeki üniversitelerde öğrenim görmekte olan öğrencilerden oluşmaktadır. Çalışmanın örneklemine dair ayrıntılı açıklama Tablo 1'de verilmiştir.

Tablo 1. Örneklemin illere ve programlara göre dağılımı

\begin{tabular}{llll}
\hline & Fen Bilgisi & Formasyon & Toplam \\
\hline Bartın & 148 & - & 148 \\
Hatay & 120 & 99 & 219 \\
Kilis & 38 & 139 & 177 \\
Uşak & 100 & 37 & 137 \\
Toplam & $\mathbf{4 0 6}$ & $\mathbf{2 7 5}$ & $\mathbf{6 8 1}$ \\
\hline
\end{tabular}

\section{Madde Havuzu Oluşturma}

Ölçekte bulunabilecek maddeleri belirlenmesi için madde havuzu oluşturmak amacıyla; öğrencilerin fen derslerindeki başarılarını etkileyen faktörler için öğrenci görüşlerine başvurularak, fen başarısının belirleyici değişkenlerine ilişkin eğitim literatüründen faydalanılarak ve 5 fen eğitimcisinden oluşan uzmanlardan (2 Yrd. Doç. Dr., 3 Doç. Dr.) alınan görüşler kullanılmıştır. Maddeleri oluşturulan ölçek beşli likert türünde olup, derecelendirme "önemsiz" 1'den "önemli" 5'e doğru cevap seçenekleri oluşturulmuştur. Çalışmanın bulgular kısmında maddelerin nasıl seçildiği detaylandırılmıştır. Öğrenci görüşlerini almak için onlardan fen başarılarını etkileyen faktörleri gruplar halinde tartışmaları ve tartışma sonuçlarını maddeler halinde yazmaları istenmiştir.

\section{Kapsam ve Görünüş Geçerliği}

Ölçeğin görünüş geçerliğinin sağlanması için madde havuzunda oluşturulan maddeler 30 fen bilgisi öğretmen adayları tarafından inceletilmiş ve görüşleri alınarak sağlanmıştır.

Ölçeğin kapsam geçerliğinin belirlenmesi uzman görüşleri çerçevesinde sağlanmıştır. Uzmanlar var olan literatür ve çerçevesinde maddeleri incelemişlerdir. Uzman değerlendirmesi sürecinde 5 fen eğitimcisi birbirinden habersiz madde havuzunda yer alan maddeleri 
değerlendirmiş ve görüşlerini bildirmişlerdir. Uzmanlardan alınan görüşler doğrultusunda bazı maddelerde iyileştirmeler yapılmış, bazılarının ise ölçekten çıkarılmasına karar verilmiştir.

\section{Yapı Geçerliği}

Ölçeğin yapı geçerliğinin ortaya konulması amacıyla madde analizi ve faktör analizleri yapılmıştır.

Ölçek geliştirme sürecince madde analizi yapılmasının amacı belirli bir yapıyı diğer yapılar ile karıştırmadan ölçebilecek maddelerin seçilmesi ve bu şekilde tutarlı bir ölçek oluşturulmasıdır (Bindak, 2005).

Alt ve üst grup madde puan ortalamalarına dayalı madde analizi yapılmış ve ölçekte yer alan maddelerin ayırt edicilik güçleri belirlenmeye çalışılmıştır. Bu amaçla fen başarısına etki eden faktörler ölçeğinde yer alan her bir maddenin üst grup ve alt grup da yer alan öğrenciler tarafından derecelendirme puan ortalamaları arasındaki farkın $t$ değeri hesaplanmıştır. Ayrıca test maddelerinden alınan puanlar ile testin toplam puanı arasındaki ilişkiyi açıklamak amacıyla Madde-Toplam Korelasyona Dayalı Madde Analizi yapılmıştır.

Uzman görüşleri doğrultusunda ve madde analizi çalışması ile bazı maddelerin ölçekten çıkartılması kararlaştıııldıktan sonra geriye kalan maddeler için açımlayıcı faktör analizi yapılmıştır.

Faktör analizi için verilerin uygun olması gerekmektedir. Verilerin uygunluğu için, "KMO" (Kaiser-Meyer-Olkin) ve "Bartlett Küresellik" testleri yapılmış ve AFA'da varimax dik döndürmesi kullanılmıştır. Screeplot testi incelenerek ölçeğin kaç faktöre sahip olabileceğine bakılmıştır.

Screeplot testi sonuçlarını doğrulamak için Horn'un paralel analizi yapılmıştır.

Açımlayıcı faktör analizi yapıldıktan sonra LISREL 8.8 istatistik programı ile doğrulayıcı faktör analizi yapılarak tespit edilen boyutların doğrulayıp doğrulamadığ 1 test edilmiştir.

\section{Güvenirlik}

Faktör analizi sonucu ölçekte kalan maddeler için güvenirlik çalışması yapılmış ve Cronbach-Alpha iç tutarlık katsayısı hesaplanmıştır. Hesaplanan katsayı esas alınarak geliştirilen ölçeğin ne derece güvenilir olduğuna karar verilmiştir. Bununla beraber ölçeğin alt boyutlarındaki öğrenci cevapları arasındaki ilişkiye de bakılmıştır. 


\section{Bulgular ve Yorum}

\section{Madde Oluşturma}

Öğrencilerin fen derslerindeki başarılarını etkileyen faktörler fen başarısının belirleyici değişkenlerine ilişkin eğitim literatüründen (Wang\&Staver, 1996; McKnight\&Schmidt, 1998; Lytton\&Pyryt, 1998; Yore et al., 2002; Enders\&Tofighi, 2007; Areepattamannil\&Kaur, 2013) faydalanılarak belirlenmiştir. Bununla beraber madde oluşturmada 5 fen eğitimcisinden oluşan uzmanların görüşleri dikkate alınmıştır. Madde havuzu oluşturmada esas alınan diğer önemli çalışma ise Tatar, Tüysüz, İlhan ve Tosun (2014) tarafından yapılan 341 öğrencilerin fen başarısı üzerine etki eden faktörler hakkındaki görüşlerinin belirlendiği nitel çalışmadır. Tatar vd. (2014) yaptığı çalışmada fen başarılarını etkileyen faktörleri öğrencilerden gruplar halinde tartışarak yazmaları istenmiştir ve görüşler nitel olarak analiz edilerek frekans sayıları çıkarılmıştır. Bu çalışmada böylece öğrenci görüşünden, literatürden ve uzman görüşlerinden hareketle araştırmacılar tarafından fen başarısına etki eden faktörler ölçeği için madde havuzu oluşturulmuştur. Madde havuzunda başlangıçta 67 madde yer almaktadır. Bu maddeler araştırmacılar tarafından öğrenci, öğretim programı, öğrenme ortamı, öğretmen ve materyal adı altında beş alt boyutta toplanmak istenmiştir. Bunun üzerine bu alt boyutlarda yer almayan 1, 14, 16, 19, 20, 44, 47, 56, 59, 61, 62, 63, 64, 65 ve 67 . maddelerin ölçekten çıkarılmasına karar verilmiştir.

\section{Kapsam Geçerliği}

Ölçeğin kapsam geçerliği için fen başarısını etkileyen faktörler ölçeğinde yer alacak maddelerin belirlenmesi aşamasında uzman görüşlerine başvurulmuştur. 5 fen eğitimcisi birbirinden habersiz madde havuzunda yer alan maddeleri değerlendirmiş ve görüşlerini bildirmişlerdir. Uzman görüşleri doğrultusunda bazı maddelerde iyileştirmeler yapılmış, bazılarının ise ölçekten çıarılmasına karar verilmiştir. Bu aşamada 3, 6, 8, 23, 32, 35, 39, 46 ve 58. maddelerin ölçekten çıkarılmasına karar verilmiştir. "Madde-8: Öğrencinin fen dersine yönelik ilgi ve tutumu" maddesi hem ilgi hem de tutum ölçmeye yönelik bir madde olduğundan, ölçek maddelerinde tek bir önerme cümlesi olması gerektiği düşüncesinden hareketle ölçekten çıkarılmasına karar verilmiştir. Benzer şekilde "Madde-39: Öğretmenlerin fen derslerinin öğretiminde nitelikli ve deneyimli olması" maddesi de hem nitelik hem de deneyim ölçmeye yönelik bir madde olduğundan ölçekten çıkarılmasına karar verilmiştir. 


\section{Alt ve Üst Grup Madde Puan Ortalamalarına Dayalı Madde Analizi}

Ölçekte yer alan maddelerin ayırt edicilik güçleri belirlenmeye çalışılmıştır. Bu amaçla fen başarısına etki eden faktörler ölçeğinde yer alan her bir maddenin üst grup ve alt grupta yer alan öğrenciler tarafından derecelendirme puan ortalamaları arasındaki farkın $t$ değeri hesaplanmıştır. 681 üniversite öğrencisine uygulanan ölçekten elde edilen toplam puanlar yüksekten düşüğe doğru sıralanarak, alt ve üst gruplar 183'er kişiden oluşturulmuştur. Yapılan analiz sonuçları Tablo 2'de verilmiştir. 
Tablo 2. Ortalama, standart sapma ve $t$ değerleri

\begin{tabular}{|c|c|c|c|c|c|c|c|c|c|c|c|}
\hline$\sum^{\frac{\pi}{\pi}} \frac{\pi}{z} z$ & Grup & $\bar{X}$ & SD & $t$ & $\mathrm{p}$ & 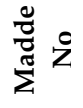 & Grup & $\bar{X}$ & SD & $t$ & $\mathrm{p}$ \\
\hline \multirow{2}{*}{2} & Alt & 4.18 & .940 & -8.772 & .000 & \multirow{2}{*}{33} & Alt & 3.73 & 1.01 & -10.627 & .000 \\
\hline & Üst & 4.83 & .371 & & & & Üst & 4.67 & .647 & & \\
\hline \multirow{2}{*}{4} & Alt & 4.07 & .969 & -8.910 & .000 & \multirow[b]{2}{*}{34} & Alt & 3.95 & 1.02 & -9.216 & .000 \\
\hline & Üst & 4.79 & .503 & & & & Üst & 4.75 & .573 & & \\
\hline \multirow{2}{*}{5} & Alt & 3.27 & 1.10 & -7.783 & .000 & \multirow{2}{*}{36} & Alt & 4.11 & .887 & -9.101 & .000 \\
\hline & Üst & 4.10 & .928 & & & & Üst & 4.79 & .469 & & \\
\hline \multirow{2}{*}{7} & Alt & 3.86 & .959 & -9.209 & .000 & \multirow{2}{*}{37} & Alt & 3.82 & 1.01 & -9.442 & .000 \\
\hline & Üst & 4.65 & .644 & & & & Üst & 4.65 & .617 & & \\
\hline \multirow{2}{*}{9} & Alt & 3.85 & 1.05 & -9.048 & .000 & \multirow{2}{*}{38} & Alt & 3.41 & 1.16 & -7.633 & .000 \\
\hline & Üst & 4.66 & .605 & & & & Üst & 4.27 & .978 & & \\
\hline \multirow{2}{*}{10} & Alt & 3.46 & 1.02 & - & .000 & \multirow{2}{*}{40} & Alt & 3.80 & 1.14 & -10.060 & .000 \\
\hline & Üst & 4.59 & .593 & 12.963 & & & Üst & 4.74 & .526 & & \\
\hline \multirow{2}{*}{11} & Alt & 3.45 & .964 & - & .000 & \multirow{2}{*}{41} & Alt & 3.86 & .885 & -13.961 & .000 \\
\hline & Üst & 4.60 & .654 & 13.253 & & & Üst & 4.85 & .365 & & \\
\hline \multirow{2}{*}{12} & Alt & 3.87 & 1.07 & - & .000 & \multirow{2}{*}{42} & Alt & 4.08 & .925 & -11.340 & .000 \\
\hline & Üst & 4.83 & .463 & 11.028 & & & Üst & 4.90 & .316 & & \\
\hline \multirow{2}{*}{13} & Alt & 3.78 & .997 & -9.240 & .000 & \multirow{2}{*}{43} & Alt & 3.83 & .949 & -12.227 & .000 \\
\hline & Üst & 4.58 & .622 & & & & Üst & 4.80 & .504 & & \\
\hline \multirow[t]{2}{*}{15} & Alt & 4.39 & .865 & -5.919 & .000 & \multirow{2}{*}{45} & Alt & 2.36 & 1.08 & -13.109 & .000 \\
\hline & Üst & 4.82 & .459 & & & & Üst & 3.91 & 1.17 & & \\
\hline \multirow{2}{*}{17} & Alt & 3.96 & 1.02 & -9.251 & .000 & 48 & Alt & 3.43 & 1.26 & -9.971 & .000 \\
\hline & Üst & 4.74 & .507 & & & & Üst & 4.55 & .836 & & \\
\hline & Alt & 3.52 & 1.14 & - & .000 & 49 & Alt & 3.39 & 1.07 & -13.491 & .000 \\
\hline 18 & Üst & 4.54 & .685 & 10.320 & & & Üst & 4.62 & .596 & & \\
\hline & Alt & 3.34 & 1.05 & - & .000 & 50 & Alt & 4.13 & .982 & -9.575 & .000 \\
\hline 21 & Üst & 4.55 & .767 & 12.585 & & & Üst & 4.87 & .348 & & \\
\hline 22 & Alt & 2.76 & 1.53 & -4.418 & .000 & 51 & Alt & 2.87 & 1.16 & -9.162 & .000 \\
\hline 22 & Üst & 3.46 & 1.51 & & & & Üst & 3.96 & 1.10 & & \\
\hline & Alt & 3.00 & 1.20 & - & .000 & 52 & Alt & 3.15 & 1.03 & -9.950 & .000 \\
\hline 24 & Üst & 4.20 & .991 & 10.469 & & & Üst & 4.15 & .896 & & \\
\hline & Alt & 2.76 & 1.05 & - & .000 & 53 & Alt & 3.50 & 1.19 & -9.602 & .000 \\
\hline 25 & Üst & 4.30 & .828 & 15.534 & & & Üst & 4.53 & .817 & & \\
\hline & Alt & 4.00 & .966 & -9.964 & .000 & 54 & Alt & 3.22 & 1.12 & -10.650 & .000 \\
\hline 26 & Üst & 4.79 & .488 & & & & Üst & 4.33 & .854 & & \\
\hline & Alt & 3.85 & 1.00 & - & .000 & 55 & Alt & 3.36 & 1.14 & -13.318 & .000 \\
\hline 27 & Üst & 4.73 & .608 & 10.089 & & & Üst & 4.62 & .568 & & \\
\hline 28 & Alt & 3.51 & 1.00 & - & .000 & 5 & Alt & 3.90 & 1.05 & -10.910 & .000 \\
\hline 28 & Üst & 4.47 & .618 & 10.957 & & 57 & Üst & 4.82 & .447 & & \\
\hline & Alt & 3.57 & .921 & - & .000 & & Alt & 2.42 & 1.24 & -9.517 & .000 \\
\hline 29 & Üst & 4.55 & .579 & 12.153 & & 60 & Üst & 3.71 & 1.33 & & \\
\hline & Alt & 3.42 & .974 & - & .000 & & Alt & 4.20 & .877 & -9.796 & .000 \\
\hline 30 & Üst & 4.57 & .614 & 13.476 & & 66 & Üst & 4.89 & .346 & & \\
\hline & Alt & 2.90 & 1.21 & -9.446 & .000 & & & & & & \\
\hline 31 & Üst & 4.02 & 1.03 & & & & & & & & \\
\hline
\end{tabular}


Tablo 2'de üst ve alt grupların madde ortalamaları için yapılan bağımsız gruplar $\mathrm{t}$-testi sonuçları ölçekteki bütün maddeler için $(\mathrm{p}<.05)$ istatistiksel olarak anlamlı olduğundan ölçekten bu aşamada herhangi bir madde çıkartılmamıştır.

\section{Madde-Toplam Korelasyona Dayalı Madde Analizi}

Madde-toplam korelasyonu, ölçekteki her bir maddeden alınan puan ile ölçeğin toplam puanı arasındaki ilişkiyi ortaya koymaktadır. Madde-toplam korelasyonunun pozitif ve yüksek olması, maddenin benzer davranışları örneklediğini aynı zamanda testin iç tutarlılı̆̆ının da yüksek olduğunu ifade etmektedir (Büyüköztürk, 2012). Tablo 3'te madde-toplam korelasyon değeri .30'dan küçük olan maddelerin çıkartılması sonucu geriye kalan maddeler için madde toplam korelasyonu verileri yer almaktadır. 
Tablo 3. Güvenirlik değerleri (Cronbach-Alpha)

\begin{tabular}{|c|c|c|c|}
\hline 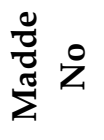 & $\begin{array}{l}\text { Madde-Toplam } \\
\text { Korelasyonları (r) }\end{array}$ & $\sum_{\Sigma}^{\frac{\pi}{\pi}} \frac{0}{2}$ & $\begin{array}{l}\text { Madde-Toplam } \\
\text { Korelasyonları (r) }\end{array}$ \\
\hline 2 & . 37 & 33 & .45 \\
\hline 4 & .37 & 34 & .38 \\
\hline 5 & $<.30$ & 36 & .39 \\
\hline 7 & .35 & 37 & .37 \\
\hline 9 & .35 & 38 & . $<30$ \\
\hline 10 & .49 & 40 & .38 \\
\hline 11 & .49 & 41 & .52 \\
\hline 12 & .44 & 42 & .48 \\
\hline 13 & .38 & 43 & .49 \\
\hline 15 &.$<30$ & 45 & .45 \\
\hline 17 & .39 & 48 & .38 \\
\hline 18 & .42 & 49 & .47 \\
\hline 21 & .45 & 50 & .40 \\
\hline 22 &.$<30$ & 51 & .35 \\
\hline 24 & .42 & 52 & .39 \\
\hline 25 & .53 & 53 & .40 \\
\hline 26 & .44 & 54 & .42 \\
\hline 27 & .40 & 55 & .46 \\
\hline 28 & .39 & 57 & .45 \\
\hline 29 & .49 & 60 & .34 \\
\hline 30 & .48 & 66 & .40 \\
\hline 31 & .38 & & \\
\hline
\end{tabular}

Tablo 3 incelendiğinde, üniversite öğrencilerinden elde edilen verilerde 5, 15, 22 ve 38. maddelerin puanları ölçek puanı ile .30 ve altında korelasyon gösterdiğinden bu aşamada ölçekten çıkartılmasına karar verilmiştir. Geriye kalan maddeler ise ölçek puanı ile yüksek derecede korelasyon göstermiş olup, .34 ile .53 arasında değişen değerler elde edildiği görülmektedir.

\section{Faktör Analizi}

15 maddenin ölçeğin teorik çerçevesine uymadığına karar verildikten sonra, 9 maddenin uzman görüssleri doğrultusunda ve 4 maddenin ise madde-toplam korelasyon değerleri .30 'dan küçük olduğu 
için ölçekten çıkartılması kararlaştırıldıktan sonra geriye kalan 39 madde için Açımlayıcı Faktör Analizi (AFA) yapılmıştır.

Çalışmada elde edilen verilerin faktör analizi yapılabilmesine uygun olması için KMO değerinin.50'den yüksek olması ve Bartlett Küresellik testinin anlamlı çıkması gerekmektedir (Çokluk, Şekercioğlu \& Büyüköztürk, 2012). 39 madde için KMO .884, Bartlett Küresellik testi $\chi^{2}$ değeri ise $6893.685(\mathrm{p}<.05)$ bulunmuştur. Bu değerler verilerin faktör analizi için uygun olduğunu göstermektedir.

Ölçekteki faktör sayısı belirleme işlemleri için AFA'davarimax dik döndürmesi kullanılmıştır. Faktör sayısını belirlemede özdeğer istatistiği incelendiğinde, ölçekteki maddelerin özdeğeri 1'den büyük faktörler anlamlı olarak ele alınmaktadır. Ölçekte öz değeri 1 den büyük 10 faktörün olduğu görülmüştür. Ayrıca, ölçeğin kaç boyutlu olduğuna karar verebilmek için çizgi grafiği (screeplot) testi incelenmiştir. Buna göre grafikte beşinci boyuttan itibaren çizgi grafiği eğimini büyük oranda kaybetmeye başladığ 1 görülmektedir. Bu durum ölçeğin beş faktör ile sinırlandırılabileceğini göstermiştir.

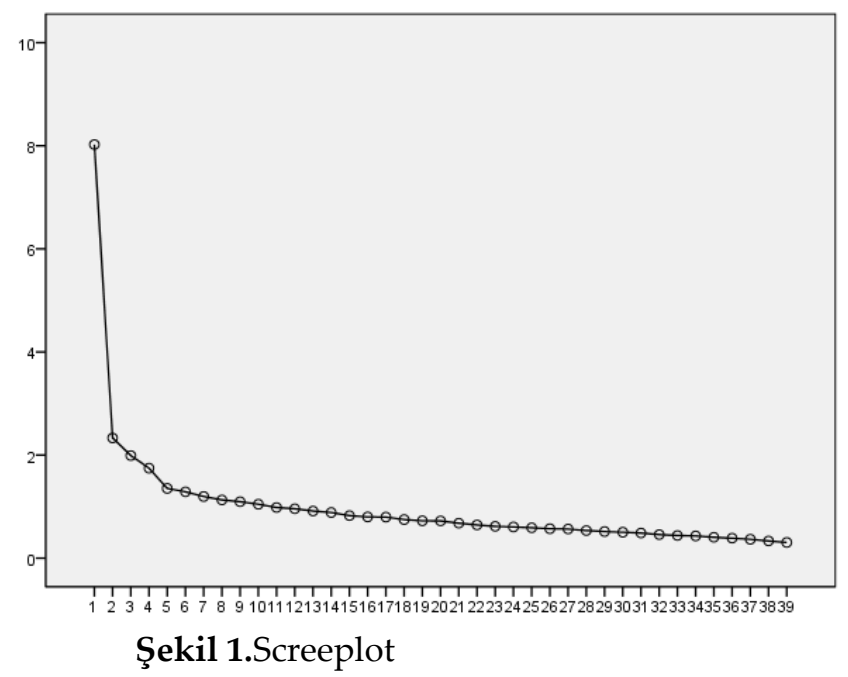

Screeplot testi sonuçlarını doğrulamak için Monte Carlo Programı yardımıyla Horn'un paralel analizi yapılmıştır. Tablo 4 de Watkins (2000) tarafından geliştirilen paralel analiz sonuçlarına yer verilmiştir. 
Tablo 4. Paralel analiz değerleri

\begin{tabular}{ccc|}
\hline Faktör sayısı & $\begin{array}{c}\text { Temel Bilişenler Analizi } \\
\text { Özdeğerleri }\end{array}$ & Paralel Analiz Değerleri \\
\hline 1 & 8.024 & 1.482 \\
2 & 2.332 & 1.427 \\
3 & 1.991 & 1.387 \\
4 & 1.746 & 1.351 \\
5 & 1.353 & 1.318 \\
6 & 1.287 & 1.292 \\
7 & 1.196 & 1.264 \\
8 & 1.129 & 1.236 \\
9 & 1.095 & 1.214 \\
10 & 1.046 & 1.191 \\
\hline
\end{tabular}

$\mathrm{Bu}$ sonuçlara göre sadece 5 faktörün temel bileşenler analizi özdeğerleri paralel analiz değerlerinden büyük, diğer bileşenlerin değerleri ise küçüktür. $\mathrm{Bu}$ sonuçlar ve yamaç-birikinti grafiği sonuçları değerlendirilerek ölçeğin 5 boyutlu olabileceğine karar verilmiştir.

Binişik olduğu tespit edilen 17, 18, 21, 28, 29, 30, 34, 40, 43 ve 53. maddeler ölçekten çıkarılarak yeniden faktör analizi yapılmıştır. Tekrar yapılan analizler sonucunda KMO değeri .862 ve Bartlett Küresellik testi $\chi^{2}$ değeri ise 4834.037 ( $p<.05)$ olan, beş faktörlü ve 29 maddeden oluşan ölçek oluşturulmuştur. 29 madde ve 5 faktörden oluşan ölçme aracının toplam varyansın \%45.045'ini açıladığı ve alt faktörlerde yer alan maddelerin teorik çerçevedeki maddelerle örtüştüğü görülmüştür. Ölçeğin faktör yükleri ve her bir faktör ve beş faktörün ölçeğe ilişkin açıkladıkları varyans Tablo 5'te sunulmuştur. 
Tablo 5. Faktör yükleri (n=681)

\begin{tabular}{|c|c|c|c|c|c|}
\hline Madde & 1. Faktör & 2. Faktör & 3. Faktör & 4. Faktör & 5. Faktör \\
\hline 4 & .69 & & & & \\
\hline 10 & .69 & & & & \\
\hline 2 & .67 & & & & \\
\hline 7 & .60 & & & & \\
\hline 11 & .59 & & & & \\
\hline 9 & .58 & & & & \\
\hline 12 & .51 & & & & \\
\hline 13 & .44 & & & & \\
\hline 37 & & .80 & & & \\
\hline 36 & & .80 & & & \\
\hline 55 & & .58 & & & \\
\hline 27 & & .52 & & & \\
\hline 41 & & .50 & & & \\
\hline 26 & & .47 & & & \\
\hline 54 & & .40 & & & \\
\hline 33 & & .33 & & & \\
\hline 50 & & & .70 & & \\
\hline 66 & & & .66 & & \\
\hline 57 & & & .64 & & \\
\hline 42 & & & .54 & & \\
\hline 48 & & & .31 & & \\
\hline 45 & & & & .68 & \\
\hline 25 & & & & .64 & \\
\hline 24 & & & & .64 & \\
\hline 60 & & & & .54 & \\
\hline 31 & & & & .53 & \\
\hline 52 & & & & & .71 \\
\hline 51 & & & & & .70 \\
\hline 49 & & & & & .39 \\
\hline 45.045 & 21.223 & 7.904 & 6.569 & 5.190 & 4.159 \\
\hline
\end{tabular}

AFA ile elde edilen alt boyutlardan birincisi öğrencidir. Sekiz maddeden öğrenci alt boyutunun faktör yükleri .69 ile .44 arasında değişmek ve toplam varyansın \%21.223'ünü açıklamaktadır. Materyal/etkinlik adlı ikinci alt boyut da sekiz maddeden oluşmakta olup, faktör yükleri 80 ile .33 arasında değişmekte ve varyansın \% 7.904'ünü açıklamaktadır. Üçüncü alt boyut olan öğretmen alt boyutu beş maddeden oluşmakta olup, 
faktör yükleri .70 ile .31 arasında değişmekte ve varyansın \%6.569'unu açıklamaktadır. Öğrenme ortamı adlı dördüncü alt boyut ise beş maddeden oluşmakta olup, faktör yükleri .68 ile .53 arasında değişmekte ve varyansın \%5.190'unu açıklamaktadır. Son boyut olan öğretim programı alt boyutu ise üç maddeden oluşmak olup, faktör yükleri .71 ile .39 arasında değişmekte ve toplam varyansın \% 4.159'unu açılamaktadır.

\section{Doğrulayıcı Faktör Analizi}

Açımlayıcı faktör analizi sonucu belirlenen faktörleri doğrulamak amacıyla aynı veriler kullanılarak doğrulayıcı faktör analizi yapılmıştır. LISREL 8.8 istatistik programı kullanılarak ölçek için Doğrulayıcı Faktör Analizi (DFA) yapılmış, aynı örneklem grubundan elde edilen verilerin beş boyutu doğrulayıp doğrulamadığı test edilmiştir. 681 öğrencinin oluşturduğu örneklemden alınan veriler için $t$ değerlerinin manidarlık düzeyi ve göstergelerin hata varyansları aşağıda verilmiştir.

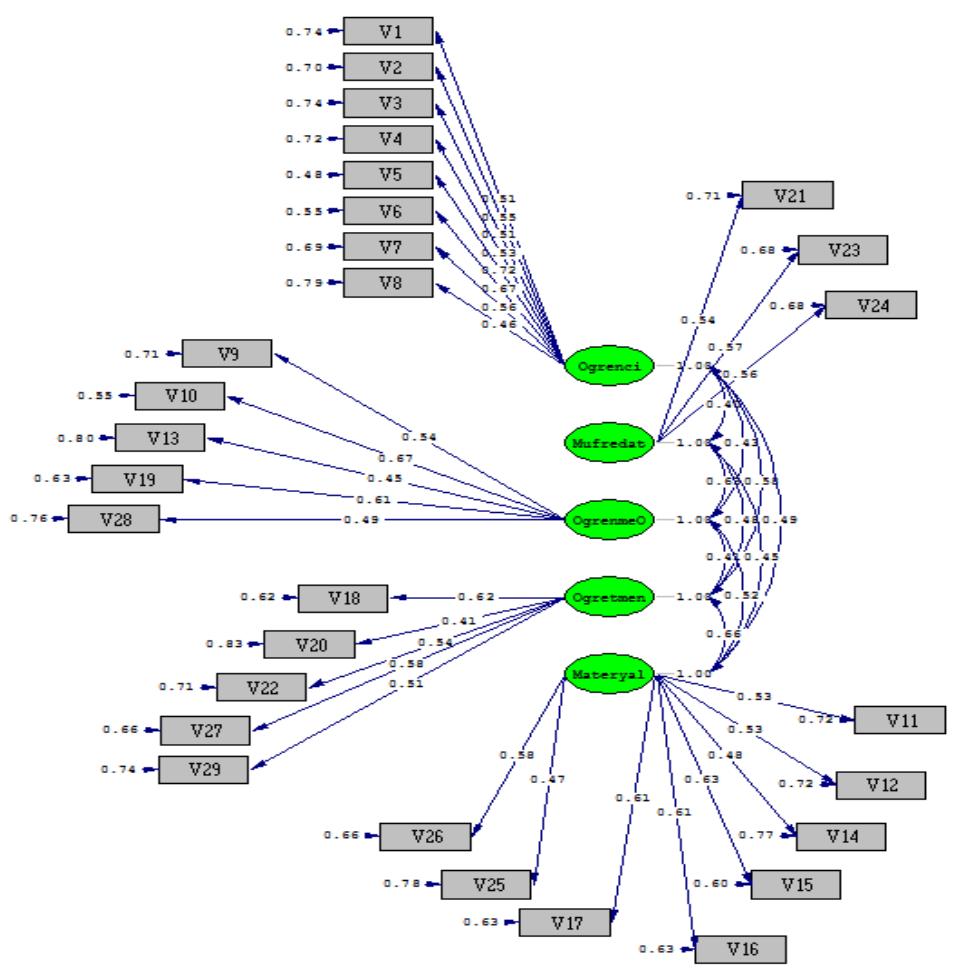

Şekil 2. Hata varyans oranları 


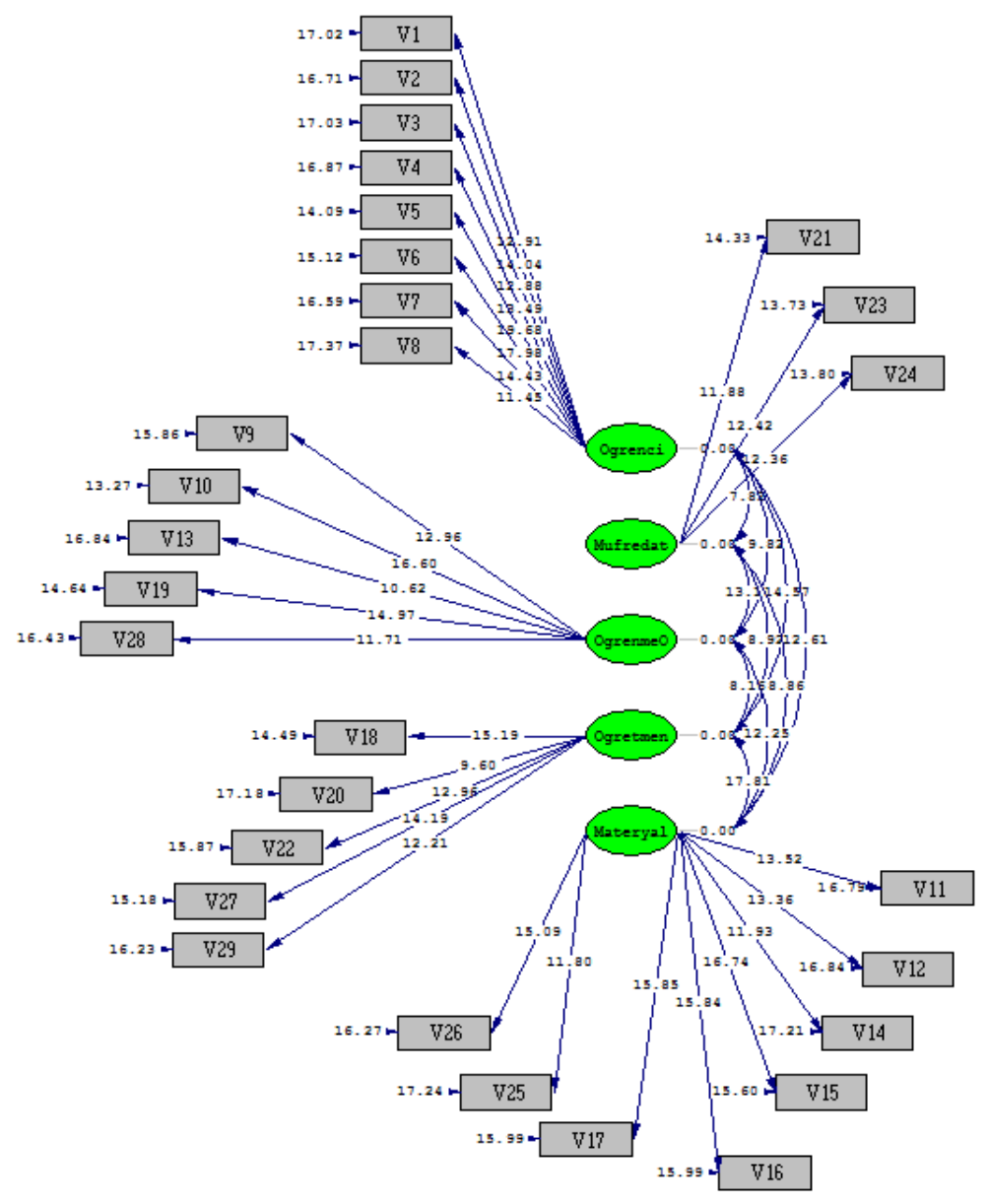

Şekil 3. $t$ değerleri

Şekil 2 ve $3^{\prime}$ de gizil değişkenlerin gözlenen değişkeni açılama durumlarına ilişkin $t$ değerleri ve gözlenen değişkenlerin hata varyansları görülmektedir. Eğer $t$ değerleri $1.96^{\prime}$ yı aşarsa .05 düzeyinde ve $2.56^{\prime} y ı$ aşarsa .01 düzeyinde manidardır (Çokluk, Şekercioğlu ve Büyüköztürk, 2012). t değerleri incelendiğinde tüm göstergelerin .01 düzeyinde manidar olduğu görülmektedir. Ayrıca gözlenen değişkenlerin hata varyanslarının da oldukça uygun değerler aldığı görülmektedir.

Yapısal eşitlik modellemesinin bir türü olan DFA'de modelin uyumu ile ilgili uyum istatistiği testleri yapılmaktadır. Bu çalışmada verilerin analizinden elde edilen uyum istatistiği indeksleri Tablo 6' da yer verilmiştir. Beklenen kovaryans matrisi ile gözlenen kovaryans matrisi 
arasındaki farkın ( $\chi^{2}$ değerinin) manidarlığı için $p$ değeri incelenmiştir. $p$ değerinin anlamlı olmaması arzu edilmesine rağmen örneklemin büyük olmasından dolayı bu çalışmada $\mathrm{p}$ değerinin anlamlı olması tolere edilmektedir (Çokluk, Şekercioğlu, \& Büyüköztürk, 2012).

Tablo 6. Uyum istatistikleri $(\mathrm{n}=681)$

\begin{tabular}{ccccccccc}
\hline \multirow{2}{*}{ Model } & $2 / \mathrm{df}$ & FI & GFI & MSEA & FI & NFI & MR & SRMR \\
\hline & & & & & & & & \\
\\
& .30 & 89 & 87 & 058 & 93 & 92 & 049 & 057 \\
\hline
\end{tabular}

DFA'de uyum değeri için $\chi^{2}$ değeri serbestlik derecesine oranlanarak değerlendirmeye alınır. Elde edilen bu oranın 5'in altında olması orta düzeyde uyumu ve 3 veya $3^{\prime}$ ün altında olması uyumun çok iyi olduğu şeklinde yorumlanır(Kline, 2005; Sümer, 2000). Tablo 6 incelendiğinde $\chi^{2} / \mathrm{df}$ oranı orta düzeyde uyuma karşıllk gelmektedir. GFI, AGFI değerleri .95 üzerinde olması mükemmel uyumu .90 'un üzerinde olması iyi uyumu göstermektedir. (Hooper, Caughlan\&Mullen, 2008). Tablo 6'daki GFI ve AGFI .90 altında olduğundan zayıf uyuma karşılık gelmektedir. CFI ve NNFI değerleri incelendiğinde ise,bu değerlerin .90'1n üzerinde olması orta düzeyde uyuma karşılık gelmektedir (Sümer, 2000). DFA sonucunda elde ettiğimiz diğer bir uyum istatistiği ise RMSEA, RMR ve standardize edilmiş $R M R$ değerleridir. Bu değerlerin .05 'den küçük olması mükemmel ve $.08^{\prime}$ den küçük olması iyi uyumu ifade ederken, (Brown, 2006, s.87; Hu \& Bentler, 1999; Jöreskog\&Sörbom, 1993), .10'dan küçük olması ise zayıf uyumu göstermektedir (Tabachnick\& Fidel, 2001). Buna göre ölçek için RMSEA değerinin iyi uyum gösterdiği ifade edilebilir Diğer taraftan RMR (.049) ve standardize edilmiş RMR (.057) değerleri incelendiğinde, RMR değerinin mükemmel ve standardize edilmiş RMR değerlerinin ise iyi uyum gösterdiği söylenebilir. Uyum istatistiklerine göre bu çalışmada DFA yapılan ölçeğin, analizi yapılan uyum istatistikleriyle iyi bir model oluşturduğu görülmekte ve faktör yapılarıyla geçerli bir ölçek olduğu yorumu yapilabilmektedir.

\section{Güvenirlik}

29 maddelik ölçeğin tamamı için Cronbach-Alpha iç tutarlık katsayısı .865 bulunurken beş alt boyutuna ait değerler .568 ile .787 arasında değişmiştir. Alt boyutlar arasında en yüksek güvenirlik katsayısı .787 ile öğrenci, en düşük güvenirlik katsayısı ise .568 ile öğretim programı alt boyutuna aittir. Materyal/etkinlik alt boyutuna ait güvenirlik katsayısı .774, 
öğretmen alt boyutunun .656 ve öğrenme ortamı alt boyutunun ise .680 olarak belirlenmiştir. Ölçeğin genelinden elde edilen değerler, geliştirilen ölçeğin güvenilir olduğunu göstermektedir.

\section{Alt boyutlar arası uyumluluk}

Ölçeğin alt boyutlarındaki öğrenci cevapları arasındaki ilişkide incelenmiştir. Bu amaçla pearson korelasyon analizi yapılmış ve bulgular tablo 7'de sunulmuştur.

Tablo 7. Pearson korelasyon analizi sonuçları

\begin{tabular}{|c|c|c|c|c|c|}
\hline Alt boyutlar & & & & & Toplam \\
\hline Öğrenci & $361^{*}$ & $400^{*}$ & $291^{*}$ & $255^{*}$ & $623^{*}$ \\
\hline Materyal/etkinlik & & $465^{*}$ & $386^{*}$ & $316^{*}$ & $691^{*}$ \\
\hline Öğretmen & & & $307^{*}$ & $311^{*}$ & $669^{*}$ \\
\hline Öğrenme ortamı & & & & $418^{*}$ & $746^{*}$ \\
\hline Öğretim programı & & & & & $715^{*}$ \\
\hline Toplam & & & & & 1 \\
\hline
\end{tabular}

*Korelasyon .01 düzeyinde anlamlıdır.

Tablo 7'ye göre ölçeğin alt boyutları arasındaki ilişkiler anlamlı ve pozitif yönlüdür. Materyal/etkinlik ile öğretmen alt boyutları puanları arasındaki ilişki en yüksektir. Öğrenci ile öğretim programı alt boyutları puanları arasındaki ilişki ise en düşüktür.

\section{Sonuç ve Tartışma}

Çalışmanın sonucunda, maddeleri öğrenci görüşleri, literatür taraması, yapı geçerliği uzman görüşleri doğrultusunda oluşturulan ve kapsam geçerliği, madde analizi, faktör analizi ve güvenirlik çalışmaları ile şekillenip değerlendirilen öğrencilerin fen başarılarına etki eden faktörleri tespit etmeye yönelik bir ölçek geliştirilmiştir. Ölçek; öğrenci, öğretmen, materyal, öğrenme ortamı ve öğretim programı şeklinde beş alt boyuttan ve toplam 29 maddeden oluşmaktadır. Ölçeğin son haliyle toplam varyansın \%45.045'ini açıkladığı ve alt faktörlerde yer alan maddelerin teorik çerçevedeki maddelerle örtüştüğü görülmüştür. Ölçeğin tamamı için Cronbach $\alpha$-iç tutarlık katsayısı .865 olarak hesaplanmıştır. 29 maddeden oluşturulan ölçek beşli likert türünde olup, derecelendirme "önemsiz" 1'den “önemli" 5'e doğru cevap seçenekleri oluşturulmuştur. Çalışma sonucunda geliştirilen ölçeğin, ilerde fen başarısı belirleyicileri üzerinde yapılan 
araştırmalar için 1 şı tutacağı geçerli ve güvenilir bir ölçek olduğu düşünülmektedir.

\section{Kaynakça}

Areepattamannil, S., \& Kaur, B. (2013). Factors predicting science achievement of immigrant and non-immigrant students: A multi level analysis. International Journal of Science and Mathematics Education, 11(5), 1183 -1207.

Berberoğlu, G., Çelebi, Ö., Özdemir, E., Uysal, E., \&Yayan, B. (2003). Üçüncü Uluslararası Matematik ve Fen Çalışmasında Türk Öğrencilerinin Başarı Düzeylerini Etkileyen Etmenler. Eğitim Bilimleri ve Uygulama, 2(3), 3-14.

Bindak, R. (2005). Tutum ölçeklerine madde seçmede kullanılan tekniklerin karşılaştırılması. Inönü Üniversitesi EğitimFakültesi Dergisi, 6(10), 1726.

Brown, T. A. (2006). Confirmatory factor analysis: For applied research. New York: Guilford.

Bursal, M. (2013). İlköğretim Öğrencilerinin 4-8. Sınıf Fen Akademik Başarılarının Boylamsal İncelenmesi: Sınıf Düzeyi ve Cinsiyet Farklılıkları. Kuram ve Uygulamada Ĕ̆itim Bilimleri, 13(2), 1141-1156.

Büyüköztürk, (2012). Sosyal bilimler için veri analizi el kitabı: İstatistik, araştırma deseni, SPSS uygulamaları ve yorum (16. Baskı). PegemA Akademi, Ankara.

Çokluk, O., Şekercioğlu, G. \& Büyüköztürk, S. (2012). Sosyal bilimler için çok değişkenli istatistik: SPSS ve LISREL uygulamaları (2. Baskı).Ankara: Pegem Akademi.

Enders, C. K. \&Tofighi, D. (2007). Centering predictor variables in crosssectional multi level models: A new look at an old issue. Psychological Methods, 12, 121-138.

Fraenkel, Wallen\& Hyun, (2012).How to Design and Evaluate Research in Education. Eighth Edition. McGraw Hill. New York.

Hooper, D.,Coughlan, J., \&Mullen, M. (2008). Structural equation modeling: Guidelines for determining model fit. The Electronic Journal of Business Research Methods, 7(2), 191-205.

Hu, L.,\& Bentler, P. M. (1999). Cutoffcriteriafor fit indexes in covariance structure analysis: Conventional criteria versus new alternatives. Structural Equation Modeling: A Multi disciplinary Journal 6(1), 1-55. 
Jöreskog, K.G.,\&Sörbom, D. (1993). Lisrel 8: Structural equation modeling with the SIMPLIS command language .Lincoln wood: Scientific Software International, Inc

Kline, R. B. (2005). Principles and practice of structural equation modeling (Second Edition). NY: Guilford Publications, Inc.

Lavonen, J. \&Laaksonen, S. (2009). Context of teaching and learning school science in Finland: Reflections on PISA 2006 results. Journal of Research in Science Teaching, 46, 922-944.

Liu, O. L., Lee, H. S., \& Linn, M. C. (2010). An investigation of teacher impact on student inquiry science performance using a hierarchical linear model. Journal of Research in Science Teaching, 47(7), 807-819

Lytton, H. \&Pyryt, M. C. (1998). Predictors of achievement in basic skills: A Canadian effective schools study. Canadian Journal of Education, 23, 281-301.

McKnight, C. C., \& Schmidt, W. H. (1998). Facing Facts in U.S. Science and Mathematics Education: Where We Stand, Where We Want to Go. Journal of Science Education and Technology, 7, 57-76.

Mohammadpour, E. (2012). A multilevel study on trends in Malaysian secondary school students' science achievement and associated school and student predictors. Science Education, 96, 1013-1046. Wiley Periodicals.

Osborne, J., Simon, S. \& Collins, S. (2003). Attitudes towards science: A review of the literature and its implications. International Journal of Science Education, 25, 1049-1079.

Ozel, M., Cağlak, S. \&Erdogan, M. (2013). Are affective factors a good predictor of science achievement? Examining the role ofaffective factors based on PISA 2006. Learning and Individual Differences. 24. 73-82.

Papanastasiou, E. C. \& Zembylas, M (2004). Differential effects of science attitudes and science achievement in Australia, Cyprus, and the USA. International Journal of Science Education, 26(3), 259-280.

Sümer, N. (2000). Yapısal eşitlik modelleri. Türk Psikoloji Yazıları,3(6), 49-74.

Tabachnick, B.G.,\& Fidel, L.S. (2001). Using multivariatestatistics (Fourth Edition). MA: Allyn\& Bacon, Inc.

Tanner, C. K. (2000). The influence of school architecture on academic achievement. Journal of Educational Administration, 38, 309-330.

Tatar, E., Tüysüz, C., İlhan, N. \&Tosun, C. (2014). Fen Derslerinde Öğrenci Başarısını Etkileyen Faktörler Hakkında Öğrenci Görüşleri. XI. Ulusal Fen Bilimleri ve Matematik Eğitimi Kongresi, Adana, 11-14 Eylül, s. 557. 
Thomson, S. \& De Bortoli, L. (2007). Exploring scientific literacy: How Australia measures up. Camberwell: ACER.

Wang, J. And Staver, J. R. (1996). An empirical approach toward the prediction of students' science achievement in the United States and Hubei, China. Journal of Research in Science Teaching, 33, 283-301.

Watkins, M.W. (2000). Monte Carlo PCA for parallel analysis (computer software). State College, PA: ED \& Psych Associates.

$\mathrm{Wu}$, Y. \& Tsai, C. (2005).Development of elementary school students' cognitive structures and information processing strategies under long-term constructivist-oriented science instruction. Science Education, 89, 822-846.

Yore, L. D., Anderson, J. O., \& Shymansky, J. A. (2002). Modeling the Relationships of Classroom Characteristics and Student Attributes to Students' Science Achievement. Annual Meeting of the National Association forResearch in Science Teaching, (New Orleans, LA). 
Ek-1

\begin{tabular}{|c|c|c|}
\hline 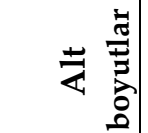 & $\begin{array}{l}\text { Madde } \\
\text { No }\end{array}$ & Ölçek maddeleri \\
\hline \multirow{8}{*}{ 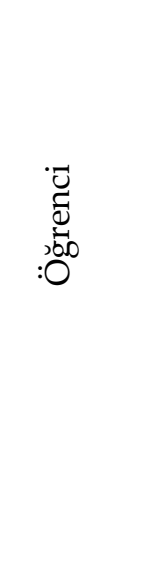 } & 2 & Öğrencinin konu tekrarı yapması \\
\hline & 4 & Öğrencinin düzenli ders çalışması \\
\hline & 7 & Öğrencinin konu ile ilgili test/soru çözmesi \\
\hline & 9 & Öğrencinin derste düzenli not tutması \\
\hline & 10 & Öğrencinin fen derslerine hazırlıklı olarak gelmesi \\
\hline & 11 & Öğrencinin fen ödevlerini yapması \\
\hline & 12 & $\begin{array}{l}\text { Öğrencinin derste anlamadığ } 1 \text { fen konuları hakkında } \\
\text { soru sorması }\end{array}$ \\
\hline & 13 & Öğrencinin fen derslerine aktif katılımı \\
\hline \multirow{3}{*}{ 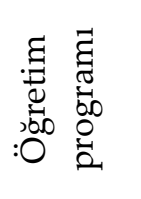 } & 49 & Fen dersi müfredatlarının yoğunluğu \\
\hline & 51 & Fen konularının soyut olması \\
\hline & 52 & Fen konularının sayısal ağırlıklı olması \\
\hline \multirow{5}{*}{ 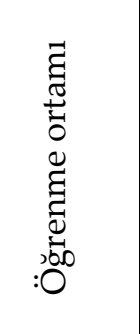 } & 24 & Fen derslerinde sınıftaki arkadaş ortamı \\
\hline & 25 & Ailenin fen çalışmaya yönelik desteği \\
\hline & 31 & Sınıfın fiziki durumu \\
\hline & 45 & Sınıftaki oturma düzeni \\
\hline & 60 & Ailede fene meraklı birinin olması \\
\hline \multirow{5}{*}{ 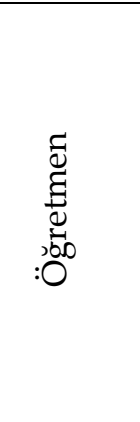 } & 50 & $\begin{array}{l}\text { Konuların öğrencilerin merakını uyandırabilecek bir } \\
\text { şekilde anlatılması }\end{array}$ \\
\hline & 66 & Öğretmenin sınıfta kontrolü sağlaması \\
\hline & 57 & Öğretmenin derse motive olması \\
\hline & 42 & $\begin{array}{l}\text { Öğretmenlerin gelişen bilim karşısında kendini } \\
\text { sürekli yenilemesi }\end{array}$ \\
\hline & 48 & $\begin{array}{l}\text { Öğrenciler arasındaki bireysel farklılıkları dikkate } \\
\text { alması }\end{array}$ \\
\hline
\end{tabular}


Y. KARAKUYU, E. TATAR, C. TOSUN, C. TÜYSÜZ, N. ILLHAN | 340

\begin{tabular}{|l|l|l|}
\hline \multirow{2}{*}{} & 37 & Deney yapma sıklığı \\
\cline { 2 - 3 } & 36 & Laboratuvarı kullanma \\
\cline { 2 - 3 } & 55 & Fen konuları ile ilgili proje yaptırılması \\
\cline { 2 - 3 } & 27 & Derste teknoloji kullanımı \\
\cline { 2 - 3 } & 41 & Eğitim araç gereçlerinin yeterli olması \\
\cline { 2 - 3 } & 26 & Derslerde uygulamalı etkinlikler yapma \\
\cline { 2 - 3 } & 54 & Derslerin bilgisayar ve internet destekli işlenmesi \\
\cline { 2 - 3 } & 33 & $\begin{array}{l}\text { Öğretmenin ders kitapları dişında farklı ders } \\
\text { materyalleri kullanması }\end{array}$ \\
\cline { 2 - 3 } & 33
\end{tabular}

